\title{
Isolation of Leishmania promastigote flagella
}

Tom Beneke $^{1 *}$, François Demay ${ }^{1 *}$, Richard J. Wheeler ${ }^{1,2}$ and Eva Gluenz ${ }^{1}$

${ }^{1}$ Sir William Dunn School of Pathology, University of Oxford, South Parks Road, Oxford OX1 3RE, UK

${ }^{2}$ Peter Medawar Building for Pathogen Research, Nuffield Department of Medicine, University of Oxford, South Parks Road, Oxford OX1 3SY, UK

corresponding author: eva.gluenz@path.ox.ac.uk

* equal contributions

\section{Running Head}

Isolation of flagella

\begin{abstract}
Eukaryotic flagella are conserved multifunctional organelles with roles in motility, intercellular interactions and signal transduction. Leishmania possess a single flagellum at all stages of their life cycle. Flagella of promastigote forms in the fly are long and motile, with a canonical 9+2 microtubule axoneme and an extra-axonemal paraflagellar rod (PFR). This protocol describes a simple method for the isolation of Leishmania mexicana promastigote flagella, optimised to yield intact flagella that retain both the cytoskeletal elements $(9+2$ axoneme and PFR) and the surrounding membrane. The isolated flagella and deflagellated cell bodies are suitable for analysis by electron microscopy, protein mass spectrometry and lipidomics.
\end{abstract}

\section{Keywords}

Leishmania, kinetoplastids, flagella, cell fractionation 


\section{Introduction}

Eukaryotic flagella and cilia are highly conserved structures. Motile flagella typically have a 9+2 microtubule (MT) structure, where a nine-fold symmetric cylinder of doublet microtubules surrounds a central pair of singlet MTs (CP). The coordinated activity of dynein motor proteins anchored on the doublet MTs generates a flagellar waveform, thought to be regulated by the $\mathrm{CP}$ and associated protein complexes. Cilia with a simpler 9+0 MT architecture typically perform sensory functions, which can be mediated through the interactions of external stimuli with receptors localised to the ciliary membrane [1]. Proteomic studies of diverse ciliated cell types [2-5], including trypanosomatids [6-9], have shown that flagella and cilia are composed of several hundred proteins, with a core set of evolutionarily conserved proteins and lineage-specific elaborations and losses [10]. Genetic studies and biochemical analyses of wild type and mutant flagella enabled the development of models for dynein-driven motility $[11,12]$ and advances in cryo-electron microscopy now help to test and refine these models $[13,14]$. Recent technological advances in gene editing have accelerated the rate at which knockout mutants can be produced [15] and offer opportunities for precision editing to alter just a few residues in a protein, for example. Further biochemical studies on wild type and mutant Leishmania flagella thus have the potential to yield new insights into the mechanisms underpinning the diverse functions of this fascinating organelle, which includes motility, cell morphogenesis, attachment to the insect vector and possibly sensory functions $[16,17]$

Here we developed a protocol for the isolation of Leishmania mexicana promastigote flagella (Figure 1), optimised to yield intact flagella that retain both the cytoskeletal elements $(9+2$ axoneme and paraflagellar rod (PFR)) and the surrounding membrane, leaving the basal body and transition zone (TZ) in the deflagellated cell body (Figure 2A). This will enable studies both on the cytoskeletal apparatus driving motility as well as interrogation of surface and membrane-associated molecules and their potential role in adhesion and signalling. 
The widespread interest in flagella and cilia produced numerous deciliation / deflagellation protocols for different cells, starting with the first reports of isolating cilia from microorganisms such as Tetrahymena in the 1950s and 60s $[18,19]$, culminating in an optimised procedure that combined a calcium shock with $2-4$ shearings using a $10 \mathrm{ml}$ glass syringe fitted with an 18-G needle [20]. Subsequent work, on the green alga Chlamydomonas and other ciliated cells, produced deflagellation methods where separation of the flagella from the cell bodies typically requires application of mechanical force in conjunction with specific chemical treatments [21]. A number of protocols have been used over the years to isolate flagella or flagellar sub-fractions from trypanosomatids [22-27,6,9]. Whilst different flagellar isolation protocols follow broadly similar principles, obtaining pure fractions of the flagellar substructures of interest requires optimisation for each cell type and species. For development of the protocol described here, a number of methods based on chemical approaches such as $\mathrm{pH}$ shock, ethanol treatment or drugs like dibucaine were tried and found to yield only small quantities of free L. mexicana flagella. Ethanol treatment combined with mechanical shearing resulted in cell fixation, while treatment with different dibucaine concentrations, incubation times or mechanical assistance permeabilised the membrane and deflagellated only some cells in the population. Shearing in a Dounce type homogeniser did result in some deflagellated cells but yielded low numbers. Passaging L. mexicana promastigotes through a syringe proved the most efficient at detaching the majority of flagella but this stripped the axonemes of their membranes. A combination of syringe disruption and addition of $\mathrm{Ca}^{2+}$ finally enabled detachment of the external flagella complete with membrane. The flagella can then be isolated away from the deflagellated cell bodies by gradient centrifugation. Analysis of the cell fractions is facilitated by using an L. mexicana cell line expressing a fluorescently tagged flagellar membrane protein. The resulting flagella are suitable for downstream analysis by transmission electron microscopy, protein analysis by SDS-PAGE, western blotting and mass spectrometry [28], and lipidomics. 


\section{Materials}

Follow local rules for safe handling and containment of Leishmania spp. and handling and disposal of hazardous chemicals.

\section{Deflagellation and Density Gradient Centrifugation}

1. Phosphate buffered saline (PBS): $137 \mathrm{mM} \mathrm{NaCl}, 2.6 \mathrm{mM} \mathrm{KCl}, 8 \mathrm{mM} \mathrm{Na} 2 \mathrm{HPO}_{4}, 1.5 \mathrm{mM}$ $\mathrm{KH}_{2} \mathrm{PO}_{4}, \mathrm{pH}$ 7.2. To make a $5 x$ concentrated solution, weigh out $40 \mathrm{~g} \mathrm{NaCl}, 1 \mathrm{~g} \mathrm{KCl}, 7.1$ $\mathrm{g} \mathrm{Na}_{2} \mathrm{HPO}_{4}$ and $1.35 \mathrm{~g} \mathrm{KH}_{2} \mathrm{PO}_{4}$ and dissolve in $1 \mathrm{~L}$ water. Dilute $1: 5$ in water to make $1 \mathrm{x}$ PBS.

2. $10 \mathrm{mM}$ PIPES [see Note 1]: $10 \mathrm{mM} \mathrm{NaCl}, 10 \mathrm{mM}$ piperazine- $\mathrm{N}, \mathrm{N}^{\prime}$-bis(2-ethanesulfonic acid), $1 \mathrm{mM} \mathrm{CaCl}_{2}, 1 \mathrm{mM} \mathrm{MgCl} 2,0.32 \mathrm{M}$ sucrose, adjusted to $\mathrm{pH}$ 7.2. Add $500 \mathrm{ml} \mathrm{dH}_{2} \mathrm{O}$ to a $1 \mathrm{~L}$ glass bottle and add 10 solid $\mathrm{NaOH}$ pellets while stirring. When the pellets have dissolved add $3 \mathrm{~g}$ PIPES, $0.22 \mathrm{~g} \mathrm{CaCl}_{2} \cdot 6 \mathrm{H}_{2} \mathrm{O}, 0.2 \mathrm{~g} \mathrm{MgCl}_{2} \cdot 6 \mathrm{H}_{2} \mathrm{O}$ and $0.58 \mathrm{~g} \mathrm{NaCl}$. Titrate to $\mathrm{pH} 7.2$ while mixing, using $1 \mathrm{M} \mathrm{NaOH}$ solution. Add $109.44 \mathrm{~g}$ sucrose to this solution. Keep mixing until completely dissolved and fill up to $1 \mathrm{~L}$ with $\mathrm{dH}_{2} \mathrm{O}$.

3. $166 \mathrm{mM}$ PIPES: $166 \mathrm{mM} \mathrm{NaCl}, 166 \mathrm{mM}$ piperazine-N,N'-bis(2-ethanesulfonic acid), 16.6 $\mathrm{mM} \mathrm{CaCl}_{2}, 16.6 \mathrm{mM} \mathrm{MgCl}_{2}$, adjusted to $\mathrm{pH}$ 7.2. Prepare as indicated for $10 \mathrm{mM}$ PIPES, but omitting the sucrose.

4. $1 \mathrm{M} \mathrm{Ca}^{2+}$ solution

5. $2 \mathrm{M}$ sucrose solution

6. $5 \mathrm{mM}$ E-64: dissolve $5 \mathrm{mg}$ in $2920 \mu \mathrm{l}$ DMSO.

7. $20 \mathrm{mM}$ Leupeptin hydrochloride: dissolve $5 \mathrm{mg}$ in $525 \mu \mathrm{lddH_{2 }} \mathrm{O}$.

8. $3 \mathrm{mM}$ Pepstatin A: dissolve $5 \mathrm{mg}$ in $2425 \mu \mathrm{l} 100 \%$ ethanol and incubate for $1 \mathrm{~h}$ at $60^{\circ} \mathrm{C}$.

9. $200 \mathrm{mM}$ Phenylmethylsulfonyl fluoride (PMSF): dissolve $100 \mathrm{mg}$ in $2850 \mu 1$ 100\% methanol.

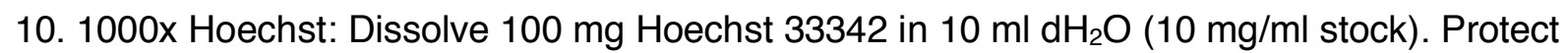
tube from light and keep under agitation overnight until completely dissolved. 
11. Equipment and consumables: $200 \mu$ l plastic gel loading pipette tip (Starlab) [see Note 2], $10 \mathrm{ml}$ disposable syringe, haemocytometer [see Note 3], microcentrifuge, benchtop centrifuge, ultracentrifuge and ultra-centrifugation tubes, phase contrast microscope, fluorescence microscope.

\section{Methods}

An overview of the workflow is shown in Figure 1.

\subsection{Preparing Cells}

1. Use an exponentially growing Leishmania promastigote culture [see Notes 4 and 5] to set up a $200 \mathrm{ml}$ culture starting with $1 \cdot 10^{6} \mathrm{cells} / \mathrm{ml}$, then grow for $\sim 24 \mathrm{~h}$ until there are $1 \cdot 10^{7} \mathrm{cells} / \mathrm{ml}$.

2. Decant culture into four $50 \mathrm{ml}$ Falcon centrifuge tubes and collect $2 \cdot 10^{9}$ cells by centrifugation at $800 \times \mathrm{g}$ for $15 \mathrm{~min}$ at $4^{\circ} \mathrm{C}$.

3. For all following steps, keep samples at $4^{\circ} \mathrm{C}$ and cool buffers on ice before adding to samples.

4. Discard supernatant and combine the four cell pellets by resuspending in a total of $20 \mathrm{ml}$ PBS and centrifuge as above.

5. Discard the supernatant and resuspended the cells in $5 \mathrm{ml} 10 \mathrm{mM}$ PIPES.

6. Place $8 \mu \mathrm{l}$ cell suspension on a microscope slide and add a small volume of $1000 \mathrm{x}$ Hoechst stock [see Note 6]. Examine sample on a fluorescence microscope (Figure 2B).

\subsection{Deflagellation}

1. Add $0.375 \mathrm{ml}$ of $1 \mathrm{M} \mathrm{Ca}^{2+}$ solution (final conc. $0.075 \mathrm{M}$ ) and protease inhibitors $(12.5 \mu \mathrm{l}$ Leupeptin, $12.5 \mu \mathrm{l}$ PMSF, $12.5 \mu \mathrm{l}$ Pepstatin A and $5 \mu \mathrm{l}$ E-64 to the cell suspension.

2. Attach a $200 \mu \mathrm{l} \mathrm{gel} \mathrm{loading} \mathrm{pipette} \mathrm{tip} \mathrm{to} \mathrm{a} 10 \mathrm{ml}$ disposable syringe. 
3. Deflagellate cells by repeatedly drawing cell suspension through the gel loading tip into the syringe and pushing out again. Perform this a total of 100 times until flagella are sheared from the Leishmania cell bodies [see Note 7].

4. Make a 1:2 dilution of the sample by mixing $10 \mu \mathrm{l}$ sample with $10 \mu \mathrm{l} 10 \mathrm{mM}$ PIPES and then dilute again 1:25 (1:50 dilution of the sample). Add $10 \mu$ of the 1:50 dilution of the sample onto a haemocytometer and quantify the number of flagella and cell bodies and the percentage of deflagellated cells in a $0.1 \mu \mathrm{l}$ square with a phase contrast microscope (Figure 2B).

5. If tagged cells are used, place $7 \mu$ of the 1:2 sample dilution on a glass microscope slide, add a small volume of 1000x Hoechst [see Note 6] and examine sample on a fluorescence microscope to quantify the percentage of flagella retaining their membrane (Figure 2B).

\subsection{Separation of Flagella and Deflagellated Cell Bodies}

Flagella and cell bodies were separated through density gradient centrifugation, using a modified version of the protocol in [9].

1. Prepare one $9 \mathrm{ml}$ sucrose-bed containing three layers of $10 \mathrm{mM}$ PIPES with $33 \%$ (upper), 53\% (middle) and 63\% (bottom) (w/v) sucrose: Mix the ingredients listed in Table 1 for each sucrose concentration. Place the $63 \%$ sucrose solution in a $15 \mathrm{ml}$ Falcon tube, then carefully layer the $53 \%$ and the $33 \%$ sucrose solutions on top.

\section{Table 1}

\begin{tabular}{|l|l|l|l|}
\hline Sucrose (\%) & $\begin{array}{l}\mathrm{V}[\mathrm{ml}] 2 \mathrm{M} \\
\text { sucrose }\end{array}$ & $\mathrm{V}[\mathrm{ml}] \mathrm{ddH}_{2} \mathrm{O}$ & $\begin{array}{l}\mathrm{V}[\mathrm{ml}] \\
\text { PIPES pH } 7.2\end{array}$ \\
\hline 33 & 1.446 & 1.374 & 0.18 \\
\hline 53 & 2.323 & 0.497 & 0.18 \\
\hline 63 & 2.761 & 0.059 & 0.18 \\
\hline
\end{tabular}

2. Carefully place the sample (from Section 3.2 above) on top of the sucrose-bed. Take care not to mix the layers.

3. Centrifuge at $800 \times g$ for $15 \mathrm{~min}$ at $4^{\circ} \mathrm{C}$. 
4. Prepare another $33 \%$ sucrose layer (as specified in Table 1) and pipette in a $15 \mathrm{ml}$ Falcon tube.

5. Collect the top layer of the first sucrose-bed ( $4.5 \mathrm{ml}$, flagella fraction) and place it on top of the $33 \%$ sucrose layer (from Step 4 above).

6. Discard the other sucrose layers, which contain a mixture of flagella and cell bodies [see Note 8].

7. Resuspend the pellet in the $63 \%$ sucrose layer in $10 \mathrm{ml} 10 \mathrm{mM}$ PIPES (contains the deflagellated cell bodies [see Note 9]) and keep on ice.

8. Centrifuge both the second sucrose-bed with the flagella fraction and the resuspended pellet (cell body fraction) at $800 \times g$ for $10 \mathrm{~min}$ at $4^{\circ} \mathrm{C}$.

9. Discard the supernatant from the cell body fraction and add $20 \mu \mathrm{l} 10 \mathrm{mM}$ PIPES to the pellet. With remnants from the supernatant the final volume should be $\sim 40 \mu \mathrm{l}$.

10. Transfer $36.5 \mu \mathrm{l}$ of this fraction to a $0.5 \mathrm{ml}$ Eppendorf tube and keep on ice.

11. Transfer the top layer of the flagella fraction to a $3.5 \mathrm{ml}$ ultra-centrifugation tube.

12. Discard the remainder of the second sucrose bed.

13. Centrifuge the flagella fraction at $100,000 \times g$ for $1 \mathrm{~h}$ at $4^{\circ} \mathrm{C}$.

14. Discard the supernatant and resuspend the pellet containing the isolated flagella in 10 mM PIPES, adding PIPES in small volumes so that the final volume is exactly $36.5 \mu$.

15. Remove $0.5 \mu \mathrm{l}$ from the flagella fraction and dilute with $10 \mathrm{mM}$ PIPES (first 1:40 and then $1: 25$, to a final dilution of $1: 1000$ ). Use the $1: 000$ dilution to determine the yield and purity [see Note 10] by counting on a haemocytometer and if a tagged cell line was used, use the $1: 40$ dilution to determine the proportion of flagella with retained membrane using a fluorescence microscope (Figure 2B).

16. Remove $0.5 \mu \mathrm{l}$ from the final cell body fraction and analyse as for the flagella fraction (Step 15 above; Figure 2B). 
17. The isolated flagella and cell bodies can then be used for protein mass spectrometry, further biochemical fractionation (Figure 2C) [see Note 11] or light and transmission electron microscopy [see Note 12].

\section{Notes}

1. PIPES buffer was used to prepare samples compatible with glutaraldehyde fixation for transmission electron microscopy analysis. An alternative buffer that works for the deflagellation protocol (but is not compatible with glutaraldehyde fixation because it contains Tris) is STC isotonic buffer (0.32 M sucrose containing $0.03 \mathrm{M}$ Tris $\mathrm{pH} 7.2$, $0.001 \mathrm{M} \mathrm{CaCl}_{2}$ ). The addition of $\mathrm{Ca}^{2+}$ to the deflagellation buffer precludes resuspending samples in PBS as we noted a phosphate precipitation.

2. Plastic gel loading tips are used instead of syringe needles for safety reasons to avoid the possibility of needle stick-injuries. The tips used in this protocol had an inner diameter of $\sim 0.35 \mathrm{~mm}$, which corresponds to a 23 gauge needle.

3. For counting of live Leishmania, we recommend using disposable haemocytometers such as "C-Chip" Digital Bio, Neubauer Improved DMC-N01 for safety reasons.

4. The density and health of the Leishmania culture at the start before homogenization are crucial to ensure a high yield.

5. This protocol can be used with Leishmania wild-type promastigotes or with a cell line that expresses fluorescently tagged proteins marking subcellular structures of interest. Expression of the small myristoylated protein 1 (SMP1 [29]; LmxM.20.1310) fused to a fluorescent protein at the C-terminus (e.g. SMP1::GFP) allows monitoring of the presence of the flagellar membrane throughout the isolation procedure. Tagged cell lines can be generated by transgene expression from an episome [30], using CRISPR-Cas9 tagging [15] or Fusion PCR tagging [31]. 
6. To achieve this, use a P10 pipette with tip and set pipette to $1 \mu$ l. Pipette Hoechst $1000 \mathrm{x}$ stock solution in and out. Using the same pipette tip, pipette $8 \mu \mathrm{l}$ cell suspension on the microscope slide up and down.

7. The number of passages was optimized to yield a sample where $>99 \%$ of all cells were deflagellated.

8. Attempts to purify this layer further to increase the flagellar yield resulted in flagella without attached membrane.

9. The sucrose bed exhibited different gradient properties when using PIPES or a Trisbased buffer (STC). While a clear a pellet is visible in the $63 \%$ layer of the PIPES sucrose-bed, this is not obvious for Tris sucrose-beds. Therefore, when using STC (see Note 1), take both the $53 \%$ and $63 \%$ layer and dilute to $15 \mathrm{ml}$ with STC to recover cell bodies from the Tris sucrose-bed.

10. This protocol is optimized for high purity of isolated flagella. Expect a yield of ca. $2 \cdot 10^{8}$ flagella (about $10 \%$ of the starting material).

11. For protein analysis (e.g. mass spectrometry or Western blots) supplement cell body and flagellar fractions with $4 \mu \mathrm{l}$ pre-diluted protease inhibitor cocktail $(1 \mu$ l Leupeptin $(1: 10$ dilution of stock), $1 \mu$ PMSF (1:10 dilution of stock), $1 \mu$ Pepstatin A (1:10 dilution of stock) and $1 \mu \mathrm{l}$ E-64 (1:25 dilution of stock)). Samples can then be subjected to further fractionation (e.g. separation into detergent-soluble and insoluble components by extraction with $1 \%$ octylglucoside [28]). Samples should be resuspended in suitable sample buffer (e.g. Laemmli buffer) and these samples can be stored at $-80^{\circ} \mathrm{C}$.

12. For transmission electron microscopy, collect cell fractions by centrifugation (flagellar fraction: $30 \mathrm{~min}$ at 18,500 $\times \mathrm{g}$; cell body fraction: $15 \mathrm{~min}, 800 \times \mathrm{g}$ ) and fix by overlaying pellets with $500 \mu 10 \mathrm{mM}$ PIPES containing $2.5 \%(\mathrm{v} / \mathrm{v})$ glutaraldehyde overnight at $4^{\circ} \mathrm{C}$. Prepare samples for transmission electron microscopy using the chemical fixation protocol described in [32]. 


\section{References}

1. Hilgendorf KI, Johnson CT, Jackson PK (2016) The primary cilium as a cellular receiver: organizing ciliary GPCR signaling. Current Opinion in Cell Biology 39:84-92. doi:10.1016/j.ceb.2016.02.008

2. Ostrowski LE, Blackburn K, Radde KM, Moyer MB, Schlatzer DM, Moseley A, Boucher RC (2002) A proteomic analysis of human cilia: identification of novel components. Mol Cell Proteomics $1(6): 451-465$

3. Pazour GJ, Agrin N, Leszyk J, Witman GB (2005) Proteomic analysis of a eukaryotic cilium. The Journal of Cell Biology 170 (1):103-113. doi:10.1083/jcb.200504008

4. Ishikawa H, Thompson J, Yates JR, 3rd, Marshall WF (2012) Proteomic analysis of mammalian primary cilia. Curr Biol 22 (5):414-419. doi:10.1016/j.cub.2012.01.031

5. Amaral A, Castillo J, Estanyol JM, Ballesca JL, Ramalho-Santos J, Oliva R (2013) Human sperm tail proteome suggests new endogenous metabolic pathways. Mol Cell Proteomics 12 (2):330-342. doi:10.1074/mcp.M112.020552

6. Broadhead R, Dawe HR, Farr H, Griffiths S, Hart SR, Portman N, Shaw MK, Ginger ML, Gaskell SJ, McKean PG, Gull K (2006) Flagellar motility is required for the viability of the bloodstream trypanosome. Nature 440 (7081):224-227. doi:nature04541 [pii] 10.1038/nature04541

7. Subota I, Julkowska D, Vincensini L, Reeg N, Buisson J, Blisnick T, Huet D, Perrot S, Santi-Rocca J, Duchateau M, Hourdel V, Rousselle JC, Cayet N, Namane A, Chamot-Rooke J, Bastin P (2014) Proteomic analysis of intact flagella of procyclic Trypanosoma bruceicells identifies novel flagellar proteins with unique sub-localization and dynamics. Mol Cell Proteomics 13 (7):1769-1786. doi:10.1074/mcp.M113.033357

8. Dupe A, Dumas C, Papadopoulou B (2015) Differential subcellular localization of Leishmania Alba-domain proteins throughout the parasite development. PLoS One 10 (9):e0137243. doi:10.1371/journal.pone.0137243 
9. Oberholzer M, Langousis G, Nguyen HT, Saada EA, Shimogawa MM, Jonsson ZO, Nguyen SM, Wohlschlegel JA, Hill KL (2011) Independent analysis of the flagellum surface and matrix proteomes provides insight into flagellum signaling in mammalian-infectious Trypanosoma brucei. Mol Cell Proteomics 10 (10):M111 010538. doi:M111.010538 [pii] 10.1074/mcp.M111.010538

10. van Dam TJ, Wheway G, Slaats GG, Huynen MA, Giles RH (2013) The SYSCILIA gold standard (SCGSv1) of known ciliary components and its applications within a systems biology consortium. Cilia 2 (1):7. doi:10.1186/2046-2530-2-7

11. Lindemann CB, Lesich KA (2010) Flagellar and ciliary beating: the proven and the possible. Journal of Cell Science 123 (Pt 4):519-528. doi:10.1242/jcs.051326

12. Satir P, Heuser T, Sale WS (2014) A Structural basis for how motile cilia beat. Bioscience 64 (12):1073-1083. doi:10.1093/biosci/biu180

13. Ishikawa T (2015) Cryo-electron tomography of motile cilia and flagella. Cilia 4 (1):3. doi:10.1186/s13630-014-0012-7

14. Lin J, Nicastro D (2018) Asymmetric distribution and spatial switching of dynein activity generates ciliary motility. Science 360 (6387). doi:10.1126/science.aar1968

15. Beneke T, Madden R, Makin L, Valli J, Sunter J, Gluenz E (2017) A CRISPR Cas9 highthroughput genome editing toolkit for kinetoplastids. Royal Society Open Science 4

(5):170095. doi:10.1098/rsos.170095

16. Landfear SM, Tran KD, Sanchez MA (2015) Flagellar membrane proteins in kinetoplastid parasites. IUBMB Life 67 (9):668-676. doi:10.1002/iub.1411

17. Saada EA, Kabututu ZP, Lopez M, Shimogawa MM, Langousis G, Oberholzer M, Riestra A, Jonsson ZO, Wohlschlegel JA, Hill KL (2014) Insect stage-specific receptor adenylate cyclases are localized to distinct subdomains of the Trypanosoma brucei flagellar membrane. Eukaryotic Cell 13 (8):1064-1076. doi:10.1128/EC.00019-14

18. Child FM (1959) The characterization of the cilia of Tetrahymena pyriformis.

Experimental Cell Research 18:258-267 
19. Watson MR, Hopkins JM (1962) Isolated cilia from Tetrahymena pyriformis. Experimental Cell Research 28:280-295

20. Rosenbaum JL, Carlson K (1969) Cilia regeneration in Tetrahymena and its inhibition by colchicine. The Journal of Cell Biology 40 (2):415-425

21. Craige B, Brown JM, Witman GB (2013) Isolation of Chlamydomonas flagella. Current Protocols in Cell Biology Chapter 3:Unit 341 41-49. doi:10.1002/0471143030.cb0341s59 22. Pereira NM, de Souza W, Machado RD, de Castro FT (1977) Isolation and properties of flagella of trypanosomatids. J Protozool 24 (4):511-514

23. Segura EL, Vazquez C, Bronzina A, Campos JM, Cerisola JA, Cappa SM (1977) Antigens of the subcellular fractions of Trypanosoma cruzi. II. Flagellar and membrane fraction. J Protozool 24 (4):540-543

24. Piras MM, De Rodriguez OO, Piras R (1981) Trypanosoma cruzi: antigenic composition of axonemes and flagellar membranes of epimastigotes cultured in vitro. Experimental Parasitology $51(1): 59-73$

25. da Cunha e Silva NL, Hasson-Voloch A, de Souza W (1989) Isolation and characterization of a highly purified flagellar membrane fraction from trypanosomatids. Molecular and Biochemical Parasitology 37 (1):129-136

26. Ismach R, Cianci CM, Caulfield JP, Langer PJ, Hein A, McMahon-Pratt D (1989) Flagellar membrane and paraxial rod proteins of Leishmania: characterization employing monoclonal antibodies. J Protozool 36 (6):617-624

27. Warburg A, Tesh RB, McMahon-Pratt D (1989) Studies on the attachment of Leishmania flagella to sand fly midgut epithelium. J Protozool 36 (6):613-617

28. Beneke T, Demay F, Hookway E, Ashman N, Jeffery H, Smith J, Valli J, Becvar T, Myskova T, Lestinova T, Shafiq S, Sadlova J, Volf P, Wheeler RJ, Gluenz E (2018) Genetic dissection of a Leishmania flagellar proteome demonstrates requirement for directional motility in sand fly infections. bioRxiv 476994. doi:https://doi.org/10.1101/476994 
29. Tull D, Vince JE, Callaghan JM, Naderer T, Spurck T, McFadden GI, Currie G, Ferguson K, Bacic A, McConville MJ (2004) SMP-1, a member of a new family of small myristoylated proteins in kinetoplastid parasites, is targeted to the flagellum membrane in Leishmania. Molecular Biology of the Cell 15 (11):4775-4786. doi:10.1091/mbc.E04-06-0457

30. Tetaud E, Lecuix I, Sheldrake T, Baltz T, Fairlamb AH (2002) A new expression vector for Crithidia fasciculata and Leishmania. Molecular and Biochemical Parasitology 120 (2):195-204

31. Dean S, Sunter J, Wheeler RJ, Hodkinson I, Gluenz E, Gull K (2015) A toolkit enabling efficient, scalable and reproducible gene tagging in trypanosomatids. Open Biology 5 (1):140197. doi:10.1098/rsob.140197

32. Hoog JL, Gluenz E, Vaughan S, Gull K (2010) Ultrastructural investigation methods for Trypanosoma brucei. Methods in Cell Biology 96:175-196. doi:10.1016/S0091-

$679 \times(10) 96008-1$

\section{Figure Captions}

\section{Figure 1. Workflow of deflagellation procedure}

Schematic overview of the workflow. Red asterisk $\left(^{*}\right)$ indicate samples that should be examined microscopically to quantify yield and purity. Adapted from [28].

\section{Figure 2. Expected results}

(A) Cartoon showing the point where flagella are severed from the cell body. The basal body and proximal part of the flagellum remain attached to the cell body, releasing the external flagellum (axoneme, paraflagellar rod and membrane). (B) Composite of phase contrast images and fluorescence signal from Hoechst DNA stain (red) and SMP1::GFP (green) marking the flagellar membrane, taken at different steps of the protocol: (i) whole $L$. mexicana cells before deflagellation, (ii) after deflagellation, (iii) flagellar fraction, (iv) cell body fraction. Scale bar is $20 \mu \mathrm{m}$. Image adapted from [28]. (C) The flagellar and cell body fractions were separated into $1 \%$ octylglucoside soluble (Fs, Cs) and insoluble (Fi, Ci) fractions, separated alongside whole cell lysates (L. mex SMP1::GFP) on a 10\% 
polyacrylamide gel and stained with SYPRO Ruby Protein Gel Stain (Molecular Probes).

Distinct banding patterns are observed for each fraction. The numbers below the gel picture indicate the cell equivalent for the amount of protein loaded.

\section{Funding statement}

TB was supported by a Medical Research Council PhD studentship (15/16_MSD_836338),

FD was supported by an Erasmus grant, RW is a Sir Henry Dale Fellow, supported by

Wellcome Trust grant 211075/Z/18/Z, EG is a Royal Society University Research Fellow. 
A

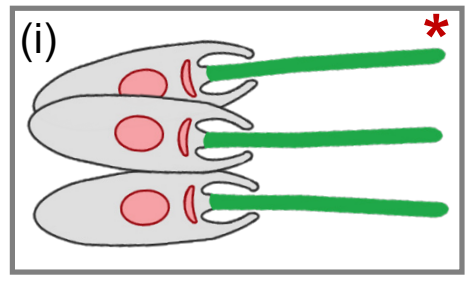

Collection

$15 \mathrm{~min}$

$\&$ Wash

$800 \mathrm{~g}$

\section{Deflagellation}

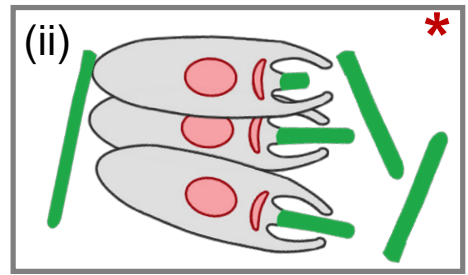

Flagella
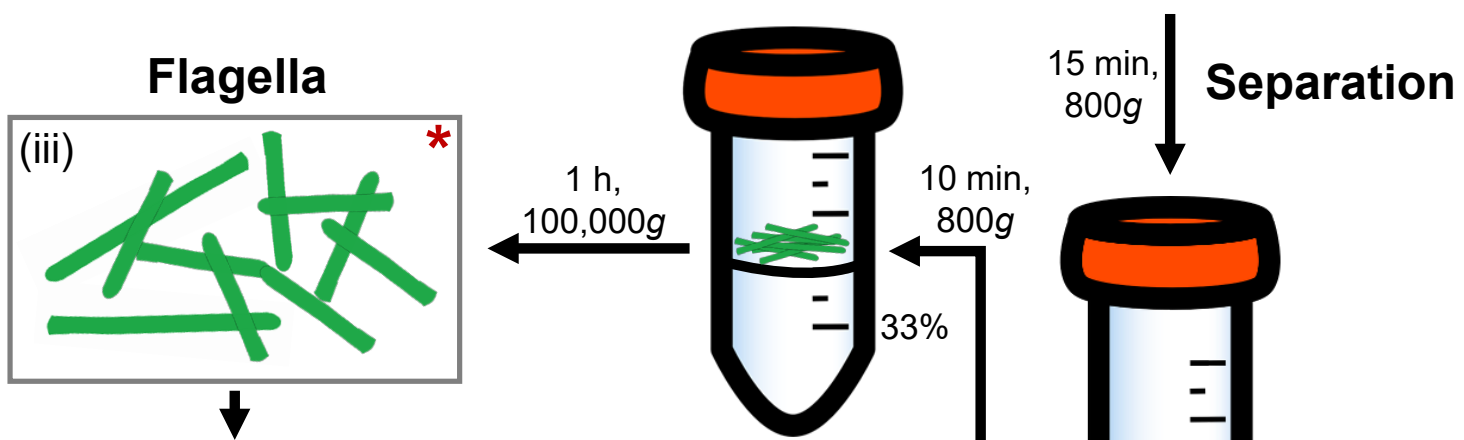

Proteomics, TEM \& other assays
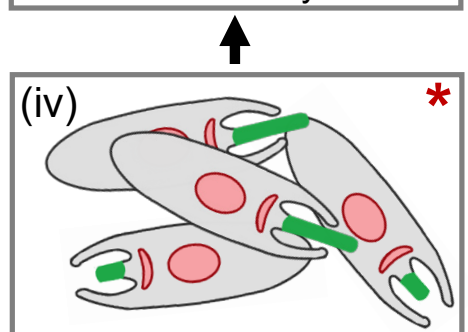
$100,000 \mathrm{~g}$

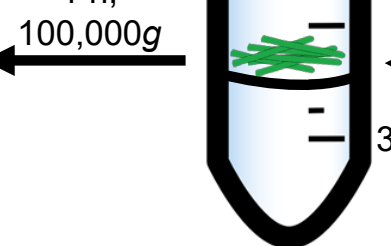

\section{$10 \mathrm{~min}$} 800

$33 \%$
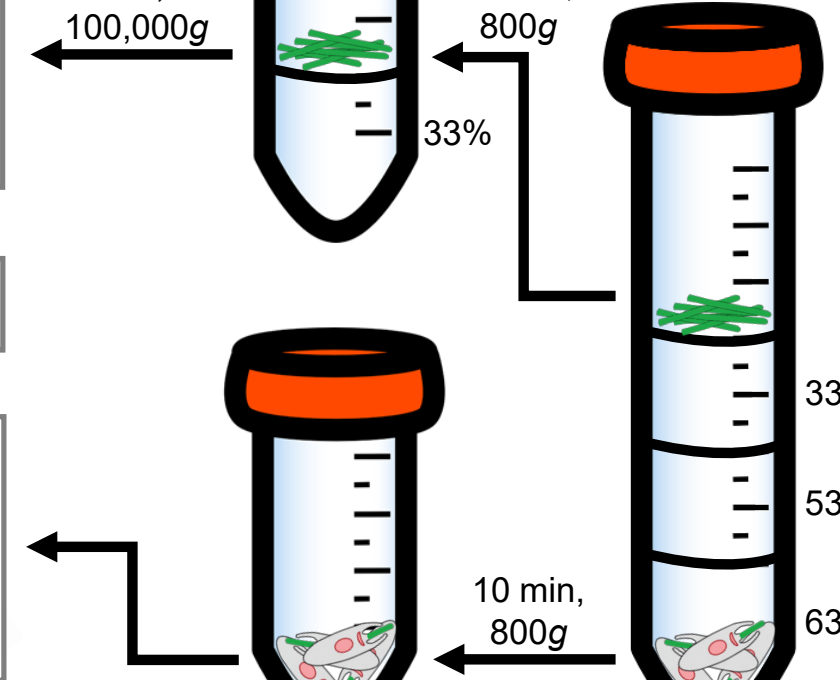

Cell bodies 


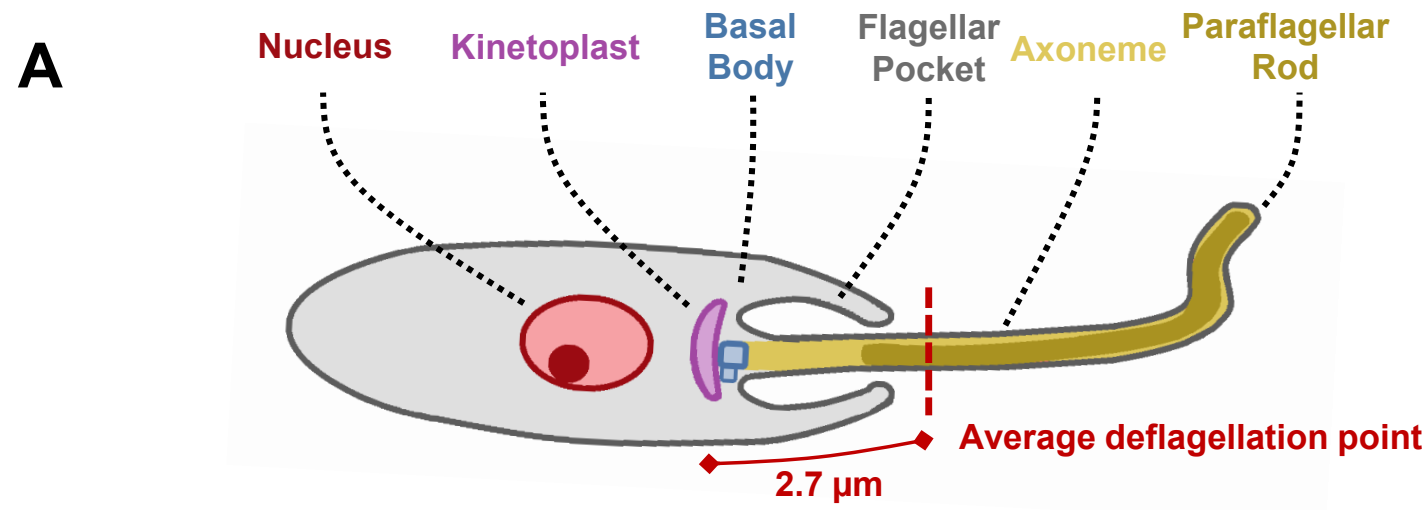

B
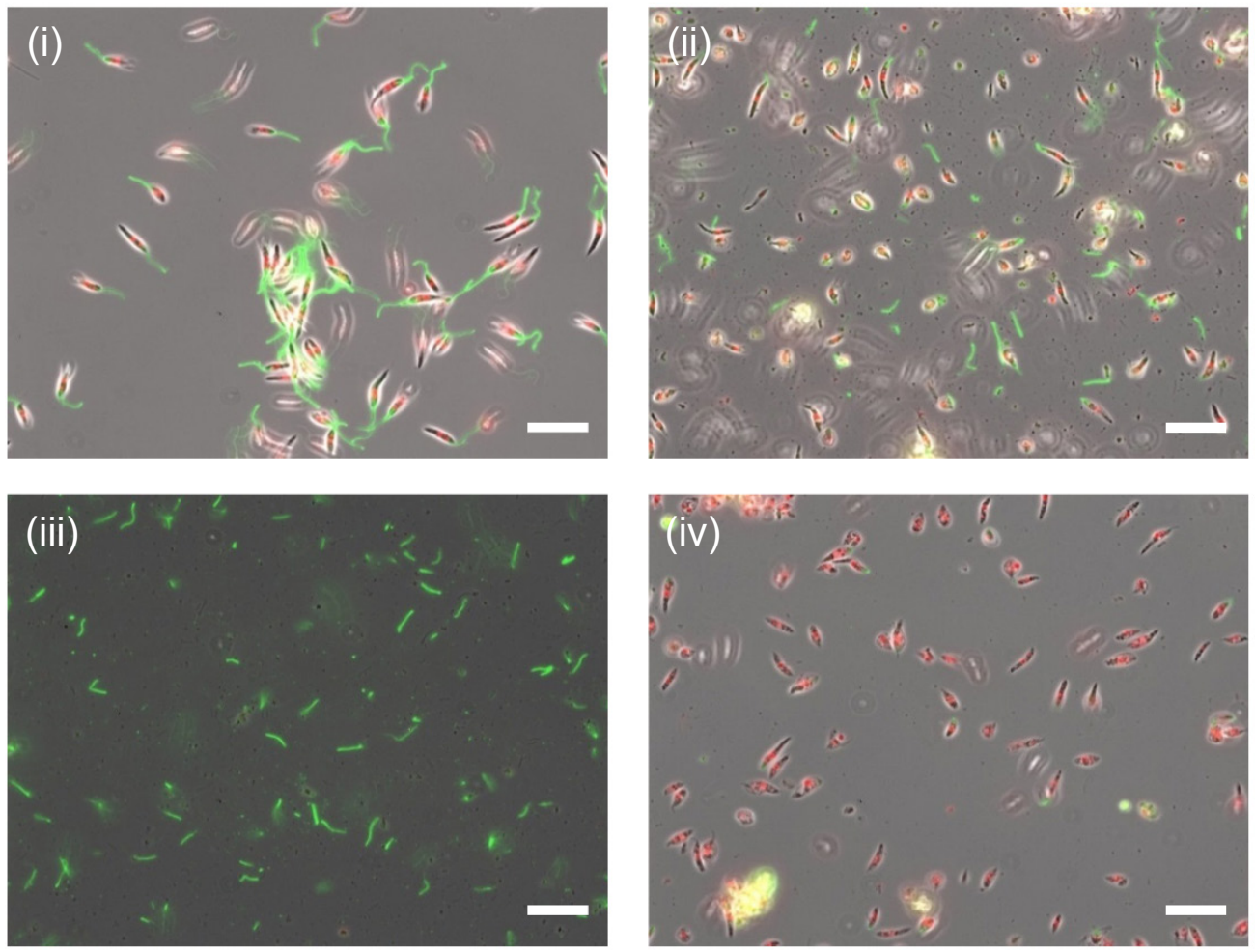

C

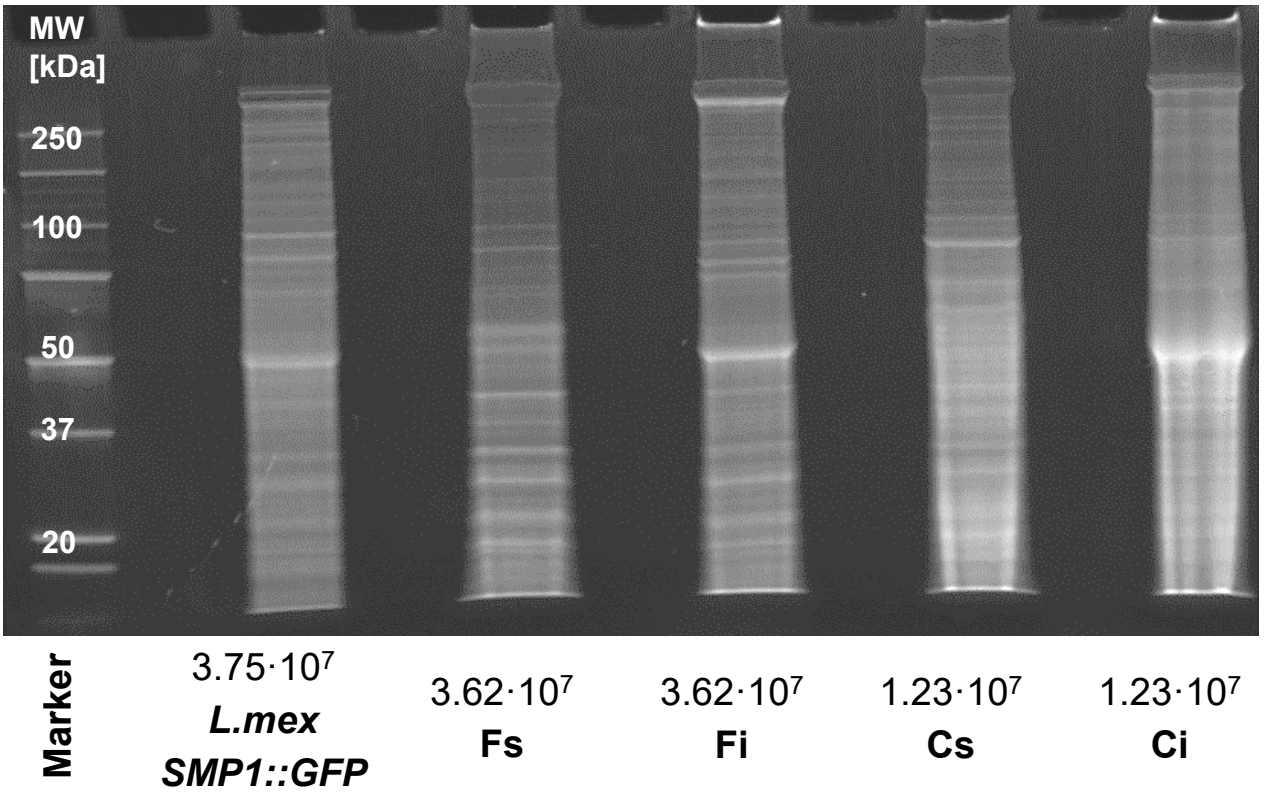

Figure 2 